\title{
ГОРИЗОНТИ СПІВПРАЦ НМАПО ІМЕНІ П. Л. ШУПИКА ТА ТДМУ ІМЕНІ І. Я. ГОРБАЧЕВСЬКОГО
}

\author{
М. В. Гребеник, О. Р. Боярчук
}

ДВНЗ “Тернопільський державний медичний університет імені І. Я. Горбачевського МОЗ Украйни”

\section{HORIZONS OF COOPERATION NATIONAL MEDICAL ACADEMY OF POSTGRADUATE EDUCATION BY P. L. SHUPYK AND TERNOPIL STATE MEDICAL UNIVERSITY BY I. YA. HORBACHEVSKY}

\author{
M. V. Hrebenyk, O. R. Boyarchuk \\ SHEI "Ternopil State Medical University by I. Ya. Horbachevsky of MPH of Ukraine"
}

\begin{abstract}
У статті окреслені основні напрямки багаторічної співпраці між провідним закладом післядипломної освіти України Національною академією післядипломної освіти імені П. Л. Шупика та Тернопільським державним медичним університетом імені І. Я. Горбачевського.
\end{abstract}

The article adduces the main areas of long-term cooperation between the leading Institution of Postgraduate Education of Ukraine - National Medical Academy of Postgraduate Education by P. L. Shupyk and Ternopil State Medical University by I. Ya. Horbachevsky.

Вступ. У жовтні 2013 року Національна медична академія післядипломної освіти (НМАПО) імені П. Л. Шупика відзначила свій 95-літній ювілей. Майже 40-літня історія відділяє ії від створення Тернопільського державного медичного інституту, сьогодні - ДВНЗ “Тернопільський державний медичний університет імені І. Я. Горбачевського МОЗ України" (ТДМУ). Якщо говорити про післядипломну освіту, то факультет післядипломної освіти у ТДМУ розпочав свою роботу у 1979 році.

Основна частина. Обидва вузи поєднують багато років плідної співпраці. 32002 року НМАПО імені П. Л. Шупика очолює професор Юрій Васильович Вороненко - видатний учений, організатор медичної освіти і науки, дійсний член Національної академії медичних наук України, заслужений діяч науки і техніки України, лауреат Державної премії України в галузі науки і техніки. Він є головним редактором журналу "Медична освіта", член редколегії журналу "Вісник соціальної гігієни та організації охорони здоров'я України”, які видаються у ТДМУ імені I. Я. Горбачевського, був учасником численних навчально-наукових конференцій, які проводились на базі Тернопільського університету. У видавництві "Укрмедкнига" було видано його монографію "Менеджмент та лідерство в медсестринстві” (2001) і підруч-

() М. В. Гребеник, О. Р. Боярчук ники "Соціальна медицина та організація охорони здоров’я” (2000, 2005).

Тісно співпрацює з нашим вузом і доктор медичних наук, професор, заслужений діяч науки і техніки України, дійсний член Міжнародної академії інформатики, Української академії інформатизації та Академії технологічних наук України Озар Петрович Мінцер, який разом з колективом своєї кафедри протягом багатьох років проводив курси тематичного удосконалення для викладачів Тернопільського університету 3 питань сучасних аспектів навчання 3 використанням інформаційних технологій, інформаційних аспектів передачі знань при безперервному професійному розвитку лікарів і провізорів, основ теорії та методики професійної освіти, дистанційного навчання, був щорічним учасником і доповідачем на конференціях з організації навчального процесу.

Звання почесного професора Тернопільського державного медичного університету імені І. Я. Горбачевського присвоєно 3 професорам Національної медичної академії імені П. Л. Шупика: академіку НАМН України Ю.В. Вороненку, академіку НАМН України Г. В. Книшову та О. П. Мінцеру.

Неодноразовим гостем у стінах нашого університету був академік НАМН України, член-кореспондент НАН України, доктор медичних наук, заслужений діяч науки і техніки України, професор Любомир Антонович Пиріг, який багато років очолював кафедру 
нефрології у НМАПО імені П. Л. Шупика, багато років був президентом Всеукраїнського лікарського товариства, сьогодні - його почесним президентом, $\epsilon$ професіоналом у своїй справі та патріотом своєї Батьківщини. За його ініціативи та за підтримки ТДМУ імені І. Я. Горбачевського у травні 2003 року в Тернополі було проведено VII з'їзд ВУЛТ.

Багато років плідної співпраці поєднують педіатричні кафедри. Так, професор кафедри неонатології НМАПО імені П. Л. Шупика О. Г. Сулима, яка в період з 1992 до 2004 року була головним спеціалістом 3 неонатології МОЗ України, підтримувала розвиток неонатологічної служби у Тернопільській області, неодноразово виступала на конференціях різного рівня, які проводили кафедри педіатрії, однією 3 перших читала відеолекції для студентів та лікарівінтернів з актуальних питань неонатології.

Давнім другом нашого університету є завідувач кафедри дитячих інфекційних хвороб та дитячої імунології, доктор медичних наук, професор, заслужений лікар України, головний спеціаліст з дитячої імунології МОЗ України Людмила Іванівна Чернишова.

Тісний взаємозв'язок поєднує кафедру сімейної медицини НМАПО імені П. Л. Шупика, яка є опорною для післядипломної освіти сімейних лікарів, $\mathrm{i}$ кафедру терапії та сімейної медицини навчально-наукового інституту післядипломної освіти ТДМУ імені I. Я. Горбачевського. На жаль, передчасно пішов із життя директор Інституту сімейної медицини, завідувач кафедри сімейної медицини, доктор медичних наук, професор Григорій Іванович Лисенко, який зробив вагомий внесок у розвиток сімейної медицини в Україні. 24-25 жовтня 2013 року спільно з НМАПО імені П. Л. Шупика, за рахунок залучення інформаційних ресурсів обох закладів в режимі реального часу для різних регіонів України було проведено науковопрактичну конференцію з міжнародною участю “Актуальні проблеми сімейної медицини в Україні”, присвячену 25-річчю сімейної медицини в Україні та 15річчю Асоціації сімейних лікарів в Україні.

Професор кафедри кардіології та функціональної діагностики НМАПО імені П. Л. Шупика Олег Йосипович Жарінов люб'язно погодився провести майстер-клас для лікарів-інтернів та лікарів-курсантів факультету післядипломної освіти ТДМУ імені І. Я. Горбачевського “Фібриляція передсердь, тактика ведення, невирішені проблеми". Викладачі даної кафедри - доктори медичних наук Максим Юрійович Соколов та Борис Михайлович Тодуров внесли великий вклад у розвиток інтервенційної кардіології у Тернопільській області. За їх сприянням проведені показові оперативні втручання, круглі столи, науково-практичні конференції. У листопаді 2013 року відбувся науково-практичний симпозіум "Гострий коронарний синдром, стандарти сучасної реперфузійної терапії. Проблеми та рішення".

Плідна співпраця поєднує кафедру акушерства та гінекології ННІПО ТДМУ й кафедру акушерства, гінекології та перинатології НМАПО імені П. Л. Шупика на чолі з завідувачем кафедри, професором Юрієм Петровичем Вдовиченком в рамках україношвейцарської програми '“Здоров'я матері та дитини". Розробки цієї програми сприяють сталому розвитку післядипломної освіти медиків в Україні. Електронні навчальні посібники "Ведення нормальних пологів”, "Багатоплідна вагітність”, “СРАР як метод респіраторної терапії новонароджених", які було створено у попередній фазі Програми, $є$ добре знаними і запитаними серед широкого загалу українських лікарів. Завдяки схваленню і рекомендаціям MO3 України згадані посібники використовуються також і в закладах післядипломної освіти. Належна якість цих навчальних матеріалів постала не випадково, а завдяки добре обгрунтованій методології їх розробки, що мала на меті не просто виклад навчальної інформації у зручному (електронному) форматі, але, перш за все, - формування у лікаря компетентністних знань і навичок, як цього й вимагають сучасні міжнародні освітні стандарти.

Викладачі кафедри акушерства та гінекології ННІПО нашого університету неодноразово брали участь у науково-практичних конференціях, конгресах, які проводились на базі академії імені П. Л. Шупика. В майстер-класі по кровотечах та проведенню органозберігаючих операцій при масивних маткових кровотечах з участю міжнародних експертів взяли участь проф. А. В. Бойчук, доц. В. І. Коптюх, доц. О. І. Хлібовська.

На прохання Міністерства охорони здоров'я України було розроблено і видано посібник “Ведення фізіологічної вагітності" для викладачів 3 проведення ТУ для лікарів “Загальна практика - сімейна медицина”, який виданий з грифом ЦМК МОЗ України. До складу робочої групи з розробки посібника входили фахівці і експерти з Національної медичної академії післядипломної освіти ім. П. Л. Шупика, Харківської медичної академії післядипломної освіти, Тернопільського державного медичного університету, ІваноФранківського національного медичного університету та Львівського національного медичного університету.

В цьому році лікарі-інтерни ТДМУ імені І. Я. Горбачевського отримали унікальну можливість пройти 
курси стажування на кафедрі дитячої кардіології та кардіохірургії (завідувач кафедри - Надія Миколаївна Руденко, доктор медичних наук, професор, заслужений діяч науки і техніки України), яка розміщена на базі Науково-практичного медичного центру дитячої кардіології та кардіохірургії МОЗ України (директор - доктор медичних наук, заслужений лікар України, професор Ілля Миколайович Смець).

Дирекція навчально-наукового інституту післядипломної освіти співпрацює з навчальним відділом НМАПО імені П. Л. Шупика (начальник - доц. О. М. Вернер) в плані обміну навчально-методичною документацією. Ольга Михайлівна - досвідчений організатор, яка завжди допомагає у вирішенні складних питань, за що висловлюємо їй велику подяку.

Висновок. Співпраця ДВНЗ “Тернопільський державний медичний університет імені I. Я. Горбачевського МОЗ України" з провідним закладом післядипломної освіти України-Національною медичною академією післядипломної освіти імені П. Л. Шупика відкриває нові можливості підвищення якості підготовки лікарів-інтернів та лікарів-курсантів, росту професійної і педагогічної майстерності викладачів закладу. 